\begin{tabular}{|c|c|}
\hline & $\begin{array}{l}\text { International Journal of Trend in Scientific } \\
\text { Research and Development (IJTSRD) }\end{array}$ \\
\hline 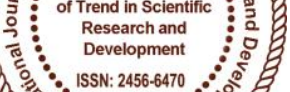 & International Open Access Journal \\
\hline$a=-z^{2}$ & ISSN No: $2456-6470$ | www.ijtsrd.com | Volume - 2 | Issue -3 \\
\hline
\end{tabular}

\title{
A Research Paper on "Impact of GST on Service Sector of India"
}

\author{
Prof. Vinayak R Gramopadhye \\ Assistant Professor, Vasantraodada Patil \\ Institute of Management Studies and \\ Research, Sangli, Maharashtra, India
}

\author{
Prof. Milind M Samudre \\ Assistant Professor, Vasantraodada Patil \\ Institute of Management Studies and \\ Research, Sangli, Maharashtra, India
}

\begin{abstract}
Introduction and implementation of Goods and Services Tax (GST) in India has its favourable and unfavourable impacts on the three sectors of an economy i.e. primary, secondary and tertiary sector. Service sector plays a major role in a developing economy in terms of generation of foreign currency. The services sector in India has been the most important sector in terms of contribution to national and state incomes, trade flows, FDI inflows, and employment. The services sector is the dominant sector in India's GDP. The present paper is an attempt to study the impact of levying of GST on service sector.
\end{abstract}

Keywords: Goods and Services Tax (GST), Service sector, trade flows, FDI

\section{INTRODUCTION:}

\section{Goods \& Services Tax}

Goods \& Services Tax Law introduced from $1^{\text {st }}$ July 2017 is a comprehensive, multi-stage, destinationbased tax that is levied on every value addition. Goods and Service Tax is an indirect tax levied on the supply of goods and services. GST Law has replaced many indirect tax laws that previously existed in India, helping to reduce complexity in the payment and collection of indirect taxes.. The new system has ushered a significant change in taxation levels and rules connected to it. The tax slab is expected to be increasing from $15 \%$ to $18 \%$ for most of the services. While this may translate to higher cost of services to the end consumer, GST also presents a whole lot of opportunities, pushing ease of business.

\section{IMPORTANCE OF SERVICE SECTOR:}

The service sector is an important component of a country's economy. India is a strong services-led economy with the sector generating a significant amount of employment opportunities and contributing to the GDP. It contributed around $66.1 \%$ of India's Gross Value Added (GVA) growth in 2015-16. Thus it is the biggest source of attraction for Foreign Direct Investment (FDI), and an important net foreign exchange earner. Some of the core areas of service are banking and financial services, IT and ITES, outsourcing, research and development, transportation, telecommunications, real estate and professional services.

It makes a direct and significant contribution to GDP and job creation, and provides vital inputs for the rest of the economy, thus having a significant effect on the overall investment climate, which is an essential determinant of growth and development. Some service sectors such as the health, education, water and sanitation sectors are also directly relevant to achieving social development objectives. The service sector accounts for a significant proportion of GDP in most countries, including low income countries, where it frequently generates over $50 \%$ of GDP. Services constitute an increasing percentage of GDP in nearly all developing countries.

\section{Literature Review}

Agogo Mawuli (2014) has studied, "Goods and Service Tax-An Appraisal" and concluded that GST is not good for underdeveloped countries and not likely to provide broad based growth to poor countries. But 
if these countries want to implement GST then the rate of GST should be less than 10\% for growth.

Dr. R. Vasanthagopal (2011) has studied "GST in India: A Big Leap in the Indirect Taxation System" and concluded that switching to flawless GST from current complicated indirect tax system in India will be a positive step in thriving Indian economy. Success of GST will lead to its acceptance by more than 130 countries in world and a new preferred form of indirect tax system in Asia also.

Ehtisham Ahmed and Satya Poddar (2009) studied, "Goods and Service Tax Reforms and Intergovernmental Consideration in India" and found that GST introduction will provide very simple and transparent tax system with increase in output and productivity of economy in India. But the benefits of GST are critically dependent on rational design of GST.

Nitin Kumar (2014) studied, "Goods and Service TaxA Way Forward" and concluded that implementation of GST in India will help in removing economic deformation by current indirect tax system and expected to encourage unbiased tax structure which is indifferent to geographical locations.

Pinki, Supriya Kamma and Richa Verma (July 2014) have studied, "Goods and Service Tax- Panacea For Indirect Tax System in India" and concluded that the new NDA government in India is positive towards implementation of GST and it is beneficial for central government, state government and as well as for consumers in long run if its implementation is backed by strong IT infrastructure.

\section{Objectives of study:}

1. To study the impact of GST implementation on service sector of India

2. To study the changes in service sector after GST implementation

3. To assess the advantages and challenges of GST

\section{Research Methodology:}

Since it is an explanatory research it is based on secondary data collected from articles, journals, newspapers and magazines. The accessible secondary data is used for research study.

\section{GST Impact}

Some of the Important Areas where the GST Impact is Visible:

\section{Services becoming Costlier}

In previous tax regime, service tax was applicable at the rate of $15 \%$ on Services rendered which includes $0.5 \%$ for Swachh Bharat Cess and $0.5 \%$ for KrishiKalyan Cess but in the Goods and Service tax regime, it has been increased up to $18 \%$ making the services and works contracts costlier. According to the Revenue secretary, the level of taxation which has been increased in the latest implemented GST structure as the minister was sure and told that the service sector is under the higher taxation of $18 \%$ from the previous $15 \%$ in the Goods and services tax framework.

\section{Impact on government Revenue}

Previously, Service tax provisions were applicable to all over India except Jammu \& Kashmir because of that Central Govt. had no right to collect service tax on the services rendered in that part of India but as per the Model Goods and Services Tax Law, GST extends to all over India including Jammu \& Kashmir and also allows Central Govt. to collect the service taxes on rendered services in the state of Jammu and Kashmir which will eventually increase the Govt. Revenue.

\section{Registration of Place of Business}

GST registration rules are quite simple for the service providers with operations in one state. They are actually liable to get more input tax credits (ITC) with less GST compliance burden. But the service providers with operations in more than one state have some major GST conformity rules to go through.

Most of the service providers with operations in multiple states will now have to register in different states to be assessed separately in each state. There are, however, certain conditions and rules that need to be fulfilled for a service provider to register across multiple states.

\section{New Challenges faced by service sector}

In respect of GST, the fact of the matter is, for those who are dealing in services, to that extent there are certain challenges. First of all, there is no centralized registration. As compared to the other jurisdictions where GST has been rolled out, services always have centralized registration. Here we will need to have 36 registrations for all the 36 states (including Union Territories)." 


\section{Impact on Software Service Industry}

There are numerous software service companies who are now tackling with the goods and service tax scheme now. Among them, there some industrial companies who state a different point of view regarding the regime. Nikhil Rungta, Managing Director of Intuit India, mentioned that "In the GST regime, it is imperative for every stakeholder in the ecosystem to upload tax. If one does not, the party that has sold the goods forces the receiving party to do so immediately or else faces the burden of not getting input tax credit." There is lesser if not fully impact on the software industry with tax scenario being lower than previous.

GST Impacts on CBLO (Collateralised Borrowing and Lending Obligation)

Under model GST, Services are defined as everything other than Goods. So CBLO also comes under services and all the rules and regulations are applied to it.

CBLO benefits from two factors fee-based activities and fund-based activities. Fee-based activities include transaction fees, processing fees, and locker charges are liable to be considered in service tax under GST. The fund-based services such as interest, investment, asset financing, and proprietary trading are exempted from the service tax.

\section{Benefits to Healthcare Services:}

Finance minister while drafting GST, ensured to make healthcare services affordable for all the people. There are no taxes on health care services to make them cheap and easily available to all. Healthcare services include care and treatment for illness, injury, deformity, pregnancy, and abnormality along with diagnosis service, patient transportation services, also clinical establishment by the hospital, nursing, clinic, and sanatorium.

Due to healthcare services are exempted from GST, the input tax credits are not available for healthcare services provider. This increased the input tax cost and affected the burden of tax on healthcare services on end-users or patients.

\section{Latest updates from service sector:}

This is the first time in three months after GST implementation that services sector has shown some improvement. According to one more report, the economy is recovering from a load of GST implementation and Nikkei India Services PMI has increased from 47.5 in August to 50.7 in September. Generally, when this index reaches above 50 , it is considered to be an exception in the economy and subsequently, the changes in the economy due to increasing business order can improve the employment rate rapidly after 2011 .

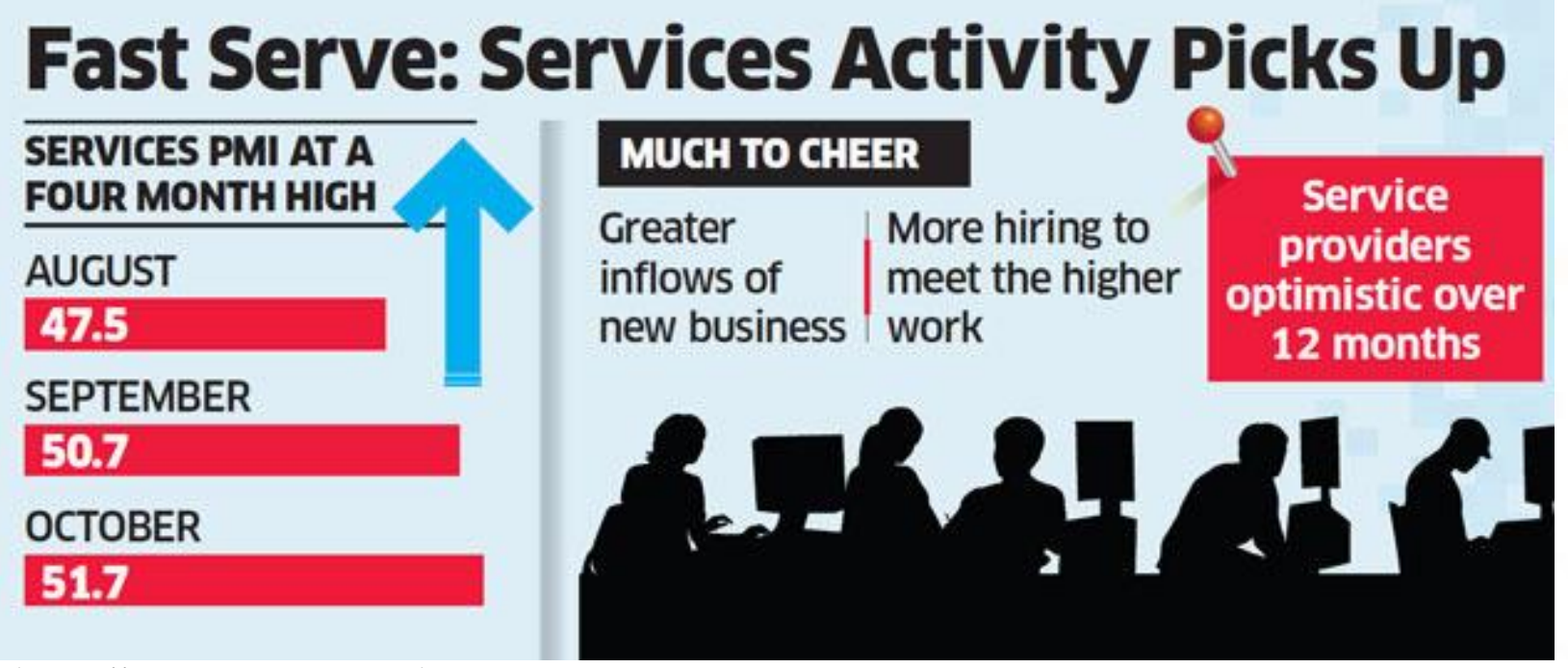

Source: https://economictimes.indiatimes.com

After GST implementation, for the first time in September 2017, GST has shown some positive signs. In September, the Nikkei India Composite PMI output has also increased to 51.1 from last month's index of
49 and it is an exceptional case for most of the economist. 
Even the core sector has shown the highest 4.9 percent hike in the August among last 5 months and the rate has grown rapidly in September also. The labour market has become strong and employment phase is recovering after 2011. The changes and improvement can be seen in all the sectors like transport, storage, and consumer services. Furthermore, the input cost has increased in September but output charge has shown sluggishness after June.

\section{CONCLUSIONS:}

The implementation of Goods and Services Tax (GST) is demonstrating its positive impact on Indian service sector. The labour market has become strong and employment phase is recovering after 2011. Although there are some challenges which need to be addressed, the economy is getting acquainted to GST and is likely to show positive impacts furthermore.

\section{REFERENCES:}

1. Indirect Taxes Committee, Institute of Chartered Accountants of India (ICAI) Goods and Services Tax (GST). 2015. Retrieved from: http://idtc.icai.org/download/Final-PPT-on-end In S Clentillic GSTICAI.pdf

2. Indian journal of Finance

3. Parkhi, Shilpa. Goods and Service Tax in India: the changing.

4. https://blog.saginfotech.com/gst-impact-onservice-sector-in-india

5. https://blog.capitalfloat.com/implications-gstservices/ 